\title{
Information effect on consumer adoption for a new beef brand in the Vietnamese market: prior knowledge, appealing the brand distinction, differentiation and similarity
}

\author{
Thu TRAN \\ Academy of Finance, Hanoi, Vietnam \\ tranthanhthu308@gmail.com \\ Masahiro MORITAKA \\ Kyushu University, Fukuoka, Japan \\ Ran LIU \\ Kyushu University, Fukuoka, Japan \\ Susumu FUKUDA \\ Kyushu University, Fukuoka, Japan
}

\begin{abstract}
The purpose of this study is to evaluate the effects of information on consumer adoption when introducing a new beef brand to the Vietnamese markets. Three variables proxy the impacts of information are prior knowledge, usage experience, and price. This study developed three pieces of advertised information and combined them with three levels of price to indicate the relevant information to diffuse at the introduction of a new brand. Three kinds of information include: (1) distinction information, which defines a new brand to be distinct from existing competitive brands; (2) differentiation information, which identifies a new brand to be different from one existing brand; (3) similarity information, which defines a new brand to be similar to one existing brand. The survey was conducted via direct interviews with 480 customers at the food outlets in Ho Chi Minh City, Vietnam. The ordered logit model was applied to examine the influence of each kind of information on consumer preferences for a new beef brand. The results indicated that (1) the effect of information on consumer adoption for a new brand at early stage depends on how that information defines the new brand in consumers' perception; (2) the distinction information generates the highest economic added value; (3) the similarity information creates the information bias at introduction; (4) the usage experience can be diagnostic for the information bias.
\end{abstract}

Keywords: information; prior knowledge; brand distinction; brand differentiation; brand similarity; introduction stage; Japanese Wagyu beef; Vietnam.

Please cite the article as follows: Tran, T., Moritaka, M., Liu, R., and Fukuda, S. (2018), "Information effect on consumer adoption for a new beef brand in the Vietnamese market: prior knowledge, appealing the brand distinction, differentiation and similarity", Management \& Marketing. Challenges for the Knowledge Society, Vol., 13 No 3, pp. 1014-1034, DOI: 10.2478/mmcks-2018-0020.

\section{Introduction}

One major problem with a new brand/product introduction is information asymmetry due to the knowledge gap between marketing agencies and consumers (Rogers, 2003). Firms should launch the appropriate marketing communication program to shorten the knowledge gap and to enhance the learning process of consumers about the new brand or product.

The information processing is the major period in consumer buying model. Understanding this process provides marketing agencies with a lot of benefits, especially 
the relevant information in diffusion to reduce the failure rate at the early stage. Nicosia (1966), the first scholar developed the consumer-buying model for a new product, expressed the importance of information in the adoption process. More specifically, Rogers (1983) clustered the market into four groups based on the knowledge of the innovation. The hierarchy of the cognition process indicated the focus on enhancing the consumer learning at the introduction stage. Inconsistency, Schiffman and Kanuk (2007) developed the multi-stage adoption process of consumers for a new brand/product. The combination of awareness and trials illustrated the importance of information in the adoption behavior. Although theories have stated the role of information at introduction stage, there is a lack of studies to quantify its impacts as well as to apply the theoretical models in a particular marketing situation.

To some extent, the importance of information in consumer behavior is examined via the impacts of advertising. Economists in the new industrial organization indicated the economic value of information based on the consumer theory (Stigler, 1961; Nelson, 1970; 1974; Becker and Murphy, 1993). Empirical studies in this direction investigated how generic advertising affect the aggregate demand through price elasticity (Banović et al., 2009; Bredahl, 2004; Brester and Schroeder, 1995; Froehlich et al., 2009; Erdem and Keane, 1996; Ackerberg, 2003) with the lack of consideration of advertising contents. Hence, there exists a call for not only further studies on the content of ads but also empirical evidence for consumers' direct responses to various advertising scenarios.

This study validated the previous conclusions about the role of information at the introduction stage through an empirical study on the consumers' direct responses. We quantified various impacts of information on consumer adoption for a new brand to answer following questions. (1) Whether or not firms can influence the consumer adoption through using the information to reduce the knowledge gap in the market. (2) Which kind of stimulus is stronger in the private adoption, external information versus usage experience?

To measure the impacts of information, we classified information into two groups, external stimuli and internal ones. For external stimuli, we constructed three kinds of information as three advertising scenarios, which defined the new brand in the market. Another external cue was price, which was measured by three levels. For the internal stimuli, we used the usage experience (trial or not) and the need recognition, which indicated the market potential for the new brand.

We investigated the case of Japanese Wagyu beef (JPW) in the Vietnamese market. After the official approval of importing into the Vietnamese market from April 1st, 2014, JPW became the last entrant brand of imported beef in the Vietnamese market. Exporting firms during the introduction period have struggled with a lot of difficulties since local consumers, and business partners failed to differentiate JPW from previous competitive brands, Australian Wagyu beef and Kobe beef. In such an asymmetric situation, the primary consideration of the marketers is to launch the effective promotion program to enhance the adoption of JPW.

We organized this paper into three parts. The first was a conceptual framework and hypothesis development. Second, we examined the hypotheses through the empirical models. Last, we discussed our results and concluded the study.

\section{Literature reviews and hypothesis development Brand information and consumers' evaluation of new brand at the introduction}

The importance of information at the early stage of a product was measured by the impacts of consumer knowledge about such information on consumers' evaluation of a 
new brand/product. We proposed that: (1) Information could make significant impacts on the consumers' evaluation of a new brand/product; (2) The magnitude of the effects varied with the content of information. Three potential explanations could be seen for the above statements.

First, since information reduces the uncertainty of a new brand/product and shortens the market knowledge gap (Rogers, 2003; Gatignon and Robertson, 1985; Abernethy and Franke, 1996; Alba and Hutchinson 2000; Wood and Lynch, 2002; Hansen et al., 2003; Berg, 2004; Lobb et al., 2007; Bian and Moutinho, 2011), it can enhance the adoption behaviour. Particularly, consumers in emerging markets tend to avoid newness with high probability (Erevelles et al., 2001), broad coverage of information could be considered as a leading factor for a new brand/product introduction. Second, information reduces the cost of searching and facilitates consumer learning process (Bettmann and Park, 1980; Park and Lessig, 1981; Johnson and Russo 1984; Brucks, 1985; Urbany et al., 1989; Rao and Sieben, 1992; Radecki et al., 1995, Schmidt and Spreng, 1996; Moreau et al., 2001; Bauer et al., 2005; Thøgersen, 2010). Last, information can affect the attitude, purchasing intention, and buying decision by providing consumers with specific knowledge of a new brand/ product. Lin and Chen (2006) found the significant positive impacts of prior knowledge on purchase intention and decision for insurance and catering services. Pieniak et al. (2010) indicated subjective knowledge was a key determinant of attitude and behavior toward organic vegetable consumption. A positive relation between nutrient knowledge and healthy food consumption could be seen in the study of Tepper et al. (1997). Hughner et al. (2007) expressed the lack of knowledge due to insufficient marketing as evidence of ineffective organic food promotion. Voon et al. (2011) also referred to the streams of information about organic products in Malaysia to increase the consumer knowledge and direct the attitude to these commodities. The role of information in new product development or an innovation introduction could be found in the studies of Meheswaran and Sternthal (1990); Saaksjarvi (2003); Van Kleef (2005); Zhou and Nakamoto (2007); Maenpaa et al. (2008); Zhu and Chang (2015).

Previous studies have classified the impacts of information on consumer behavior by the content of information (Ackerberg, 2001; 2003; Moreau et al., 2001; Banovic' et al., 2012). In this study, we investigated the heterogeneity in the effects of information on consumer preference for innovation by using three kinds of information, which capture three identities of a new brand concerning the standing competitors. In following with literature, we predicted that each kind of information would affect the consumers'evaluation of a new brand differently.

\section{Eating experience and consumers' evaluation of a new brand at introduction}

The positive impact of usage experience on consumer preference is concluded from some previous studies when considering usage experience as a source of brand familiarity (Laroche et al., 1996; Bredahl, 2004; Ha and Perks, 2005; Banović et al., 2012; Grunert et al., 2004; Ha and Jang, 2010) or a predictor of behavior (Thøgersen, 2002; 2010). Tran et al. (2017) indicated usage experience is the most crucial factor of consumer innovativeness toward beef brands in the Vietnamese context. The adoption behavior was moderated by the accumulated experience of a new product/brand. Hence, one could predict the usage experience significantly impacts on the consumer preference for a new product/brand.

However, usage experiences become ambiguous when being considered in the prior knowledge cluster (Raju et al., 1995). Brakus et al. (2009) expressed that 
consumption experience primarily provides consumers with a hedonic consequence. Therefore, usage experience of a particular product can subsequently create multidimensional behavior based on the dispersion between expected quality and experienced quality. In regards to JPW, the influence of user experience is less conspicuous than for industrial products or durable consumer goods since it strongly depends on personal taste, a highly invisible and abstract factor. Thus, there would be the impact of user experience on the evaluation of JPW, but no specific prediction about the sign could be pointed out.

\section{The impact of brand information and usage experience in comparison}

It could be relevant to consider that user experience might dominate subjective knowledge in explaining preference variation since actual consumption could be the most reliable source of information for individual decision-making (Smith and Swinyard, 1983; Mothersbaugh et al., 1994). Thøgersen (2002) indicated that the effect of direct experience on individual behavior consists of the experience effect and the personal norm. The stronger impact of direct experience on behavior compared to attitude could be the result of personalization of direct experience and a defensive mechanism of individual cognition. One might expect that the brand information of a premium brand could result in the exploratory behavior of consumers. However, the discrepancy between expectation and actual experiences seems to be significantly reduced when consumers can rely on their own experiences instead of external information or other person's experiences. Moreover, for a premium brand such as JPW, self-experience seems the more beneficial stimuli for consumer decision-making than subjective knowledge considering the economic value of information (Nelson, 1974). Hence, the impact of eating experience might dominate prior knowledge in comparison.

\section{Market potential and consumers' evaluation of a new brand in the introduction phase}

Market potential of a new product was defined in the theory of diffusion advanced by Bass (1969) and Roger (1983) as initial purchases (m) made by "innovators" and "imitators." Alternatively, it reflected the potential total sales of a particular product after its introduction (Tseng and $\mathrm{Hu}, 2009$ ). Studies on the success of new product development at the firm level have illustrated the role of market attractiveness. Myers and Marquis (1969) named this concept market pull with emphasis on need understanding. Cooper and Kleinschmidt (1987) indicated that market potential was one situational factor, and developed a measurement for this concept by combining market size, market growth, customer need, and the importance of the product. Brown and Eisenhardt (1995) considered three characteristics of the market in new product success including large, high growth, and low competition.

Following previous studies, we developed "market potential" for JPW with great attention to the characteristics of consumer preference for current competitors. It appeared that the satisfaction with a current brand or loyalty toward an existing brand creates a barrier to entry for the new brand entrance (Keller, 2009; Menictas et al., 2012). That led to two strategies in positioning a new product compared to competitors, namely me-too and second-but-better (Frambach et al., 2003). Scholars supporting differentiated strategies have indicated the high impact of becoming distinct in customers' perception when introducing a new product (Cooper, 1979; Cooper and Kleinschmidt, 1987). Food choice to some extent is considerably different from industrial or consumer durable goods since it is hard to standardize by systematic 
criteria. Because most consumers are not food experts, they need informative cues as similar brands to evaluate and make the purchasing decision. Hence, the market potential for JPW could be extracted from the current beef-purchasing tendency. Alternatively, investigating the competitive brands from the consumer perspective is a source of need recognition and the market possibility for a new product/brand. Moreover, the essence of the attitude to existing brands could serve as personal involvement, which expresses the potential relevance of a new beef brand to individuals. Hence, it could be reasonable to predict the positive impact of market potential on evaluation for JPW at introduction. And the knowledge of brand information and eating experience could be hypothesized as the moderators of this relation.

\section{Price as a cost cue and informative cues in consumers' evaluation of JPW}

The role of price in consumer buying process is debated between a signal indicator and an economic determinant. In the case of new product/brand introduction, due to the information imperfection, consumers tend to strongly concern about the consistency of price and actual quality and the relevancy of price related to other reference prices. Hence, the negative impact of price on consumer preference could be predicted (Rogers, 2003). However, this relation is moderated by the knowledge about a new brand/product since such information can affect the way consumers utilize the information from the price. The findings from studies on perceived quality have indicated the difference in using price as an external cue of quality. Consumers with familiarity reduced the importance of price in the evaluation, while the novices tended to be heavily influenced (Bredahl, 2004; Banović et al., 2012) by price. Moreover, the role of price in product category could be influenced by the price references to other items (Aertsens et al., 2009). Angulo and Gil (2007) considered price from the perceived risk viewpoint and stated dual roles of the price after the beef crisis, namely a cost cue and a quality cue. The quality signal of price was found in some studies when consumers' WTP depended on the brand position in the entire market (Lange et al., 1998; 2000).

\section{Hypotheses}

From the above considerations, the hypotheses of this study include:

H1: During the introduction phase of a brand/product, the information about a new brand/product made a significant impact on the consumer adoption for a new brand/ product, and the impact magnitude varied with the content of information.

H2: When introducing a new brand/product to a market, the usage experience would significantly influence the consumer adoption of the new brand/product.

H3: When introducing a new brand/product to a market, the individual usage experience could be stronger than external information in explaining consumer adoption.

H4a: When introducing a new brand/product to a market, the market potential of a new brand/product can positively impact consumer preference for the new brand/product.

H4b: The impact of market potential on consumer adoption is moderated via the knowledge of brand/product and usage experience.

H5: When introducing a new brand/product to a market, the knowledge of a new brand/product could positively moderate the impact of price on consumer preference toward a new brand/product.

In summary, Figure 1 can illustrate the conceptual framework of this study. 


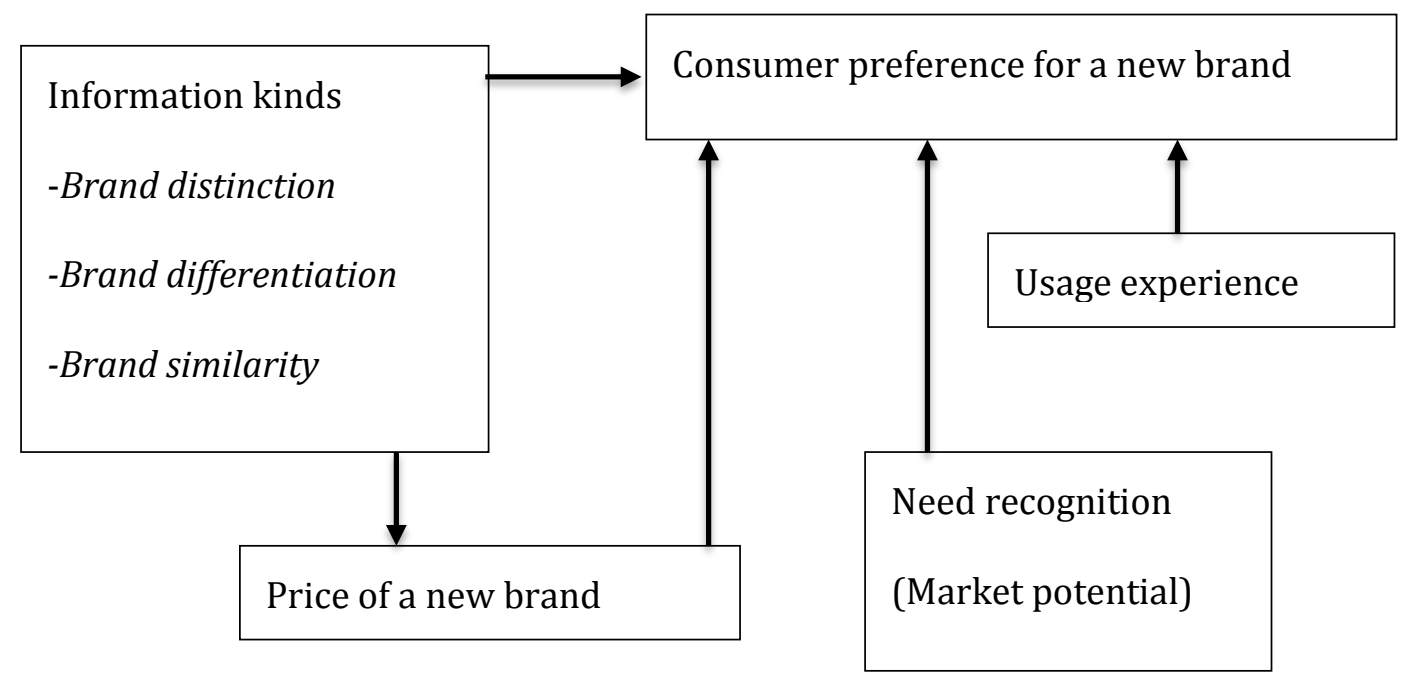

Figure 1. The conceptual framework of the study

Source: Authors' own representation.

\section{Methodology}

\section{The study area and the selection of information about JPW}

The study selected Ho Chi Minh City as the research area for consumer surveys due to the increasing demand for imported beef; especially select beef in food service venues as a result of the economic growth and cultural integration. The first survey, from January 7th to January 15th, 2015 by the Japanese Livestock Association, targeted the general situation of the beef market in HCMC. Australian beef and American beef are leading beef items in the mass market, while Kobe beef, the top-quality Japanese beef, is only served in high-end restaurants. With the official import of JPW from April 1st, 2014, the niche market for Wagyu beef is a competition between Australian Wagyu beef and JPW.

This survey also found that most of the partners in beef distribution systems in the HCMC market have misunderstandings about JPW. The main problems include an inaccurate explanation of the origin of Wagyu beef, the difference between Australian Wagyu beef and JPW, and the origin of Kobe beef. The pilot study in the retail market from April 23rd to May 18th, 2015 recognized a similar problem in the perception of consumers and managers in distribution channels1. Hence, this study used three kinds of information about JPW to measure the impacts of brand information on consumer preference at the early stage. Information 1, which explained that Wagyu is originally Japanese beef, acts as a brand distinction or non-comparative information. Information 2 indicating the significant difference between JPW and Australian Wagyu beef is named brand comparison or differentiated comparative information. The last information affirming Kobe beef as one type of JPW is the brand similarity or similar comparative information.

Table 1. Three kinds of information applied in the study

\begin{tabular}{lll}
\hline & Content & $\begin{array}{l}\text { "Wagyu beef ("WA" means Japan and “GYU" means cow) is } \\
\text { original Japanese beef. } \\
\text { Information } 1\end{array}$ \\
\cline { 2 - 3 } & Fource: Ministry of Agricultural, Fishery, and Forestry, Japan) \\
\cline { 2 - 3 } & Focus & Brand distinction \\
\hline
\end{tabular}

\footnotetext{
${ }^{1}$ The pilot study in May 2015 indicated an amazing result of Kobe beef knowledge at the customer level. Approximately $90 \%$ (in the network of 630 people) reported that they knew Kobe beef and around 30\% have eaten this beef.
} 


\begin{tabular}{|c|c|c|}
\hline & $\begin{array}{l}\text { Core } \\
\text { value }\end{array}$ & Authentic Wagyu beef made in Japan \\
\hline \multirow[t]{3}{*}{ Information 2} & Content & $\begin{array}{l}\text { Due to the salient features of Japanese Wagyu beef, in mid-1990 } \\
\text { Australia first imported full-blooded Wagyu bulls from Japan and } \\
\text { Black Angus cow from the United States to begin their Wagyu } \\
\text { crossbreeding program. Hence, only Japan can provide markets } \\
\text { with Wagyu beef of full-blooded Wagyu. } \\
\text { (Source: Australian Wagyu Association) }\end{array}$ \\
\hline & Focus & Brand differentiation \\
\hline & $\begin{array}{l}\text { Core } \\
\text { value }\end{array}$ & Full-blood Wagyu beef only from Japan \\
\hline \multirow{3}{*}{ Information 3} & Content & $\begin{array}{l}\text { Kobe beef is one kind of Wagyu beef from cattle raised in Hyogo } \\
\text { Prefecture, Japan. } \\
\text { (Source: Ministry of Agricultural, Fishery, and Forestry, Japan) }\end{array}$ \\
\hline & Focus & Brand similarity \\
\hline & $\begin{array}{l}\text { Core } \\
\text { value }\end{array}$ & Kobe beef is the beef from Japanese Wagyu pedigree \\
\hline
\end{tabular}

Source: Authors' own representation based on inline references in Table.

\section{Purchasing situation and subject selection}

Based on the first survey, this study focused on consumer behavior toward beef when dining out at intermediate restaurants or high-end restaurants. We attempted to keep the assumption that consumers would be highly involved in the purchasing situation in the screening procedure ${ }^{2}$, which ensured that all respondents had a basic background in beef and of eating beef in restaurants. We selected the respondents in the central districts of HCMC, where most of the middle and high-end beef restaurants were located. 480 respondents recruited and directly interviewed.

\section{Evaluation task}

After selecting the respondents, we brought them to a table of a restaurant (sometimes, a nearby cafeteria) and interviewed them directly. First, a full menu with five beef items was introduced to the respondents. As indicated in the previous studies, consumers could have difficulties in revealing their actual behavior when facing information overloading in the evaluation task. Hence, for each alternative, only brand (country-oforigin and kind of beef) and price were provided. The price in this study was the retail market price in beef restaurants for a 100-gram tenderloin portion in HCMC. Three levels of price were applied randomly for Japanese Wagyu beef comprising 500,000 VND $(n=161), 650,000$ VND ( $n=162)$, and 800,000 VND ( $n=157)$, while the price of other beef items was kept at constant: Australian beef at 200,000 VND; American beef at 300,000 VND; Australian Wagyu beef at 450,000 VND; and Kobe beef at 1,000,000 VND.

Next, the respondent was asked to rank each alternative based on their preference on a 5 -point Likert scale ( $1=$ completely not preferred to $5=$ very preferred). After that, they reported their subjective knowledge of JPW through answering Yes/No questions about the three kinds of the information above.

\footnotetext{
2 Respondents were asked to attend the study on beef purchased behavior at the beef restaurants freely with no monetary compensation and no information on experiments. The screening procedure includes three questions: (1) Have you ever been living in HCMC for a long time (at least five years)? (2) Do you eat beef?/Do you like eating beef? (3) Do you usually eat beef at Beef steakhouse or BBQ restaurants?
} 


\section{Analytic models}

First, we explored the emerging need for high-grade beef in the HCMC market by applying factor analysis to the preferences for four beef alternatives except for JPW.

Second, this study constructed an ordered logit model based on the random utility maximization theory (Manski, 1977; Xie and Manski, 1989; Baltas and Doyle, 2001) to test the hypotheses as follows:

We describe the latent utility of Japanese Wagyu beef of each as the following equation:

$U_{i}^{*}=\boldsymbol{B} \boldsymbol{X}_{i}+\varepsilon_{i}\left(-\infty<U_{i}^{*}<+\infty\right)$

Here:

$U_{i}^{*}$ is the utility from Japanese Wagyu beef;

$i$ indicates individual $i$

$\boldsymbol{X}_{i}$ is the transposed vector of predictors;

$\boldsymbol{B}$ is the parameter vector expressing the influences of predictors on the outcome;

$B=\left(\beta_{1}, \beta_{2}, \ldots, \beta_{m}\right)$, where $m$ is the number of predictors in the model;

$\varepsilon_{i}$ is the error term of individual $i$.

The utility from Japanese Wagyu beef for each respondent is that observed through the level of preference in the evaluation task. Hence, let $R_{i}$ denote the rank for Japanese Wagyu beef based on the individual preference. The next equation points out the relation between the latent variable (utility) and the observed outcome (preference level):

$R_{i}=j$ if $\mu_{j-1}<U_{i}^{*} \leq \mu_{j}$

Here:

$j$ indicates the $j$ th level of preference, $j=1$ to 5 ;

$\mu_{j}$ is the utility threshold of preference level $j\left(-\infty \leq \mu_{j} \leq+\infty\right)$.

Therefore, the probability at which individual $i$ selects preference rank $j$ is expressed as:

$$
\begin{aligned}
& \quad p_{i j}=\operatorname{Pr}\left(R_{i}=j\right)=\operatorname{Pr}\left(\mu_{j-1}<U_{i}^{*} \leq \mu_{j}\right)=\operatorname{Pr}\left[\mu_{j-1}-\left(\boldsymbol{B}_{i}\right)<\varepsilon_{i} \leq \mu_{j}-\left(\boldsymbol{B} \boldsymbol{X}_{i}\right)\right] \\
& =F\left[\mu_{j}-\left(\boldsymbol{B} \boldsymbol{X}_{i}\right)\right]-\mathrm{F}\left[\mu_{j-1}-\left(\boldsymbol{B} \boldsymbol{X}_{i}\right)\right]
\end{aligned}
$$

When $\varepsilon$ follows a logistics distribution, which has standard cumulative distribution function $F(\varepsilon)=\frac{e^{\varepsilon}}{1+e^{\varepsilon}}$, the odds ratio between preference level at $\mathrm{j}$ or higher and those at less than $\mathrm{j}$ is expressed as the following equation:

$$
\frac{\operatorname{Pr}\left(R_{i} \geq j\right)}{1-\operatorname{Pr}\left(R_{i} \geq j\right)}=e^{\boldsymbol{B} \boldsymbol{X}_{\boldsymbol{i}}-\mu_{j-1}}
$$

Hence, the natural log of the odds can be expressed as a linear function of predictors, as in the following equation:

$$
\ln \left(\frac{\operatorname{Pr}\left(R_{i} \geq j\right)}{1-\operatorname{Pr}\left(R_{i} \geq j\right)}\right)=\boldsymbol{B} \boldsymbol{X}_{i}-\mu_{j-1}
$$

The marginal effect of an increase in a predictor $X_{r}$ on the probability of selecting rank $j$ is: $\frac{\partial p_{i j}}{\partial X_{r i}}=\left\{F^{\prime}\left(\mu_{j-1}-\boldsymbol{B} \boldsymbol{X}_{\boldsymbol{i}}\right)-F^{\prime}\left(\mu_{j}-\boldsymbol{B} \boldsymbol{X}_{\boldsymbol{i}}\right)\right\} \beta_{r}$ with $r=1,2, \ldots, m$

Alternatively, the impact of one predictor on the log odds of preference level, conditioned on other explanatory variables, is expressed by the magnitude of the corresponding element of $\boldsymbol{B}$. And the cumulative probability at preference rank $j$ is calculated as $\operatorname{Pr}\left(R_{i} \geq j\right)=\frac{e^{\beta_{r}}}{1+e^{\beta_{r}}}$.

To investigate the moderated effect of an independent variable, based on the assumption that the unobserved variance was homogeneous in all groups, we constructed interaction terms and examined the coefficients of these components. 
Moreover, following Mood (2010), we calculated the average marginal effect (AME) and average partial effect (APE) for the considered variables as the following equation:

$$
A M E\left(X_{r}\right)=\frac{1}{n} \sum_{i=1}^{n} \beta_{r} F^{\prime}\left(\boldsymbol{B} \boldsymbol{X}_{\boldsymbol{i}}\right)=\frac{1}{n} \sum_{i=1}^{n} \frac{e^{\boldsymbol{B} \boldsymbol{X}_{\boldsymbol{i}}}}{\left(1+e^{\boldsymbol{B} \boldsymbol{X}_{\boldsymbol{i}}}\right)^{2}}
$$

And the partial effect of an independent variable on the outcome in a range of observation $n_{1} \in n: A P E\left(X_{r} / i \in n_{1}\right)=\sum_{1}^{n_{1}} \beta_{r} F^{\prime}\left(\boldsymbol{B} \boldsymbol{X}_{\boldsymbol{i}}\right)$

To understand the dominance of each explanatory variable, we followed the standardized coefficient alternative of Menard (2004):

$$
\left.\beta_{M r}^{*}=\left(\beta_{r}\right)\left(s_{r}\right)\left(R_{O}\right) / s_{\text {logit }\left(\widehat{U}^{*}\right.}\right)
$$

Here $\beta_{r}$ is the unstandardized logistic coefficient of predictor $r, s_{r}$ is the standard deviation of predictor $r, R_{O}$ is the square root of the OLS coefficient of logistic regression ${ }^{3}$, and $s_{\operatorname{logit}\left(\widehat{U}^{*}\right)}$ is the standard deviation of the predicted value of logistic regression.

Regarding $s_{\text {logit }\left(\widehat{U}^{*}\right)}$, let $U^{*}=\left\{\begin{array}{c}1 \text { if } R_{i} \geq j \\ 0 \text { otherwise }\end{array}\right.$.

Hence, $\operatorname{logit}\left(\widehat{U}^{*}\right)=\ln \left[\operatorname{Pr}\left(U^{*}=1\right) / \operatorname{Pr}\left(U^{*}=0\right)\right]=\boldsymbol{B} \boldsymbol{X}_{i}-\mu_{j-1}$.

In this study, the latent variable, the utility of Japanese Wagyu beef, is expressed by the following equation:

$$
\begin{aligned}
& U_{i}^{*}=\beta_{1} \text { Price }_{i}+\beta_{2} \text { LuxPrefer }_{i}+\beta_{3} \text { Know }_{i}+\beta_{4} \text { Know }_{i}+\beta_{5} \text { Know }_{i}+\beta_{6} \text { Exper }_{i} \\
& +\beta_{7} \text { Age } 1_{i}+\beta_{8} \text { Age } 2_{i}+\beta_{9} E d u c 1_{i}+\beta_{10} E d u c 2_{i}+\beta_{11} \text { Expend } 1_{i} \\
& +\beta_{12} \text { Expend } 2_{i}+\beta_{13} \text { Expend }_{i}+\beta_{14} \text { Price }_{i} * \text { Know }_{i} \\
& +\beta_{15} \text { Price }_{i} * \text { Know }_{i}+\beta_{16} \text { Price }_{i} * \text { Know }_{i}+\beta_{17} \text { LuxPrefer }_{i} * \text { Know }_{i} \\
& +\beta_{18} \text { LuxPrerfer }_{i} * \text { Know }_{i}+\beta_{19} \text { LuxPrefer }_{i} * \text { Know }_{i}+\varepsilon_{i}(1)
\end{aligned}
$$

${ }^{3}$ The coefficient of determination for logistics regression (Tonidandel and LeBreton, 2010) is the OLS Rsquare statistic:

$R^{2}=1-\frac{\sum\left(y-\widehat{y}^{2}\right.}{\sum\left(y-\overline{\bar{y}}^{2}\right.}$. Here $\hat{y}$ is the predicted value from a logit link transformation; $\mathrm{y}$ is the observed variable; and $\bar{y}$ is the mean value of the dependent variable. 
Table 2. The explanation of the main variables in the analytic models

\begin{tabular}{|c|c|c|}
\hline Variable & Description & Measurement \\
\hline \multicolumn{3}{|l|}{ Outcome } \\
\hline$R_{i}$ & $\begin{array}{l}\text { Preference of Japanese Wagyu Beef before providing } \\
\text { any information }\end{array}$ & $\begin{array}{l}\text { 1=Completely not prefer; } 2=\text { Not } \\
\text { prefer; 3=Normal; 4=Prefer; } 5=\text { =Very } \\
\text { prefer }\end{array}$ \\
\hline \multicolumn{3}{|l|}{ Predictors } \\
\hline Know1 & Whether or not a respondent knows the information 1 & 1=Know (1); 0 = don't know \\
\hline Know2 & Whether or not a respondent knows the information 2 & 1=Know (2); 0 = don't know \\
\hline Know3 & Whether or not a respondent knows the information 2 & 1=Know (3); 0 = don't know \\
\hline Exper & Whether or not they ate Japanese Wagyu beef before & $1=$ Have eaten; 0 = Never eaten \\
\hline Price & The price of JPW which is centered from the mean value & $\begin{array}{l}\text { Price }= \\
\left\{\begin{array}{l}-1.4875 \text { if } J P W \text { price }=500,000 \mathrm{VND} \\
0.0125 \text { if } \mathrm{JPW} \text { price }=650,000 \mathrm{VND} \\
1.5125 \text { if } \mathrm{JPW} \text { price }=800,000 \mathrm{VND}\end{array}\right.\end{array}$ \\
\hline LuxPrefer & Attitude to high-grade beef when dining out & $\begin{array}{l}\text { Factor score from the study on the } \\
\text { need }\end{array}$ \\
\hline Age1 & Age from 18 to 25 years old & $\begin{array}{l}=1 \text { if age from } 18 \sim 25 \text { years old; }=0 \\
\text { otherwise }\end{array}$ \\
\hline Age2 & Age above 35 years old & $\begin{array}{l}=1 \text { if age above } 35 \text { years old; }=0 \\
\text { otherwise }\end{array}$ \\
\hline Educ1 & Bachelor degree & $=1$ if get bachelor degree; $0=$ otherwise \\
\hline Educ2 & Master/Doctorate & $=1$ if get $\mathrm{M} / \mathrm{D}$ degree; $0=$ otherwise \\
\hline Expend1 & $\begin{array}{l}\text { Monthly food expenditure of a household on average } \\
\text { from } 14 \sim 20 \text { million VND }\end{array}$ & $\begin{array}{l}=1 \text { for spending } 14 \sim 20 \text { million VND } \\
\text { per month; }=0 \text { otherwise }\end{array}$ \\
\hline Expend2 & $\begin{array}{l}\text { Monthly food expenditure of a household on average } \\
\text { from } 20 \sim 26 \text { million VND }\end{array}$ & $\begin{array}{l}=1 \text { for spending } 20 \sim 26 \text { million VND } \\
\text { per month; }=0 \text { otherwise }\end{array}$ \\
\hline Expend3 & $\begin{array}{l}\text { Monthly food expenditure of a household on average } \\
\text { above } 26 \text { million VND }\end{array}$ & $\begin{array}{l}=1 \text { for spending over } 26 \text { million VND } \\
\text { per month; }=0 \text { otherwise }\end{array}$ \\
\hline
\end{tabular}

Note. LuxPrefer is the factor score for Factor named "high-grade beef preference" from the latent need exploratory study using Factor Analysis

Source: Authors' own representation.

\section{Data analysis}

\section{The latent need exploration and market potential for JPW}

This sub-study acts as the need recognition in the adoption process of consumers. The underlying hypothesis is about the existence of the emerging need for high-grade beef besides the current need for regular beef. To investigate this hypothesis, an exploratory factor analysis using a principal axis factoring extraction method and promax rotation was conducted. 
Table 3. Correlation matrix of beef item preference ${ }^{4}$

\begin{tabular}{llll}
\hline & $\begin{array}{l}\text { American } \\
\text { Beef }\end{array}$ & $\begin{array}{l}\text { Australian } \\
\text { Wagyu Beef }\end{array}$ & $\begin{array}{l}\text { Kobe } \\
\text { Beef }\end{array}$ \\
\hline Australian Beef & $.577^{* * *}$ & $.233^{* * *}$ & .070 \\
\hline American Beef & & $.383^{* * *}$ & $.182^{* * *}$ \\
\hline Australian Wagyu Beef & & & $.410^{* * *}$ \\
\hline
\end{tabular}

${ }^{* * *}$ Correlation is significant at the 0.01 level (2-tailed).

Source: Authors' own representation.

The Kaiser-Meyer-Olkin measure of sampling homogeneity was about 0.6, indicating that the data could be relevant to factor analysis. Besides, the significance of Bartlett's test of sphericity ( $p$-value $<.01$ ) pointed out that the correlation between the variables was sufficient to apply factor analysis. Applying the Kaiser-Guttman retention criterion of eigenvalues greater than 1.0, a two-factor solution was derived. These two factors accounted for $51.8 \%$ of the total variance. Table 4 presented the pattern matrix with a promax rotation.

Table 4. Pattern matrix ${ }^{5}$ and factor correlation for principal axis solution

\begin{tabular}{lll}
\hline & Factor loadings \\
\hline Australian Beef & $\mathbf{. 7 7 1}$ & -.112 \\
\hline American Beef & $\mathbf{. 7 7 2}$ & .088 \\
\hline Australian Wagyu Beef & .108 &. $\mathbf{6 6 5}$ \\
\hline Kobe Beef & -.120 & $\mathbf{6 4 3}$ \\
\hline & & Source: Authors' own representation.
\end{tabular}

As a commonly used rule, factor interpretation is made based on variables with factor loadings greater than 0.4 (Ford, MacCallum, and Tait, 1986). Thus, the model with two factors may be seen as the most reasonable solution. Factor 1, "regular beef preference" (eigenvalue $=1.955$ ), accounted for $37.8 \%$ of the variance and consisted of 2 items (Australian beef and American beef); Factor 2, "luxury beef preference" (eigenvalue = 1.092) accounted for $13.99 \%$ of the variance and included 2 items (Australian Wagyu beef and Kobe beef).

The results from the factor analysis seemed to be consistent with the conclusion of a transforming tendency in beef demand in new emerging markets, where the urban consumers with considerable increases in income afford a promising market for imported beef with high quality and food safety (Hubacek et al., 2007; Gale and Huang, 2007; Gandhi and Zhou, 2014). The two factors in this model could be seen as a tworoute attitude when eating beef in restaurants, namely "regular beef preference" or utilitarian need, and "high-grade beef preference" or expressive need. The moderate correlation between the two factors (Pearson coefficient $=0.454$ ) could be a result of the integration of culinary culture in purchasing behavior of Asian consumers (Pingali, 2007).

\footnotetext{
${ }^{4}$ Factor analysis was applied for 4 variables, Australian beef preference (mean=3.66; std. =.815), American beef preference $($ mean $=3.47$; std.=.819), Australian Wagyu beef preference $($ mean = 2.99; std. $=.791)$, and Kobe beef preference $($ mean $=3.03$; std. $=1.139)$.

${ }^{5}$ Extraction method: principal axis factoring. Rotation method: promax with Kaiser normalization.
} 
The need exploration indicated that there was a latent need for premium beef brands in the Vietnamese market. Hence, the potential market segment for JPW could be identified by the increasing meat demand in food services in emerging markets. Next, we examined the impacts of prior brand knowledge, the usage experience, market potential, and price on preference for JPW.

\section{Hypothesis testing}

Table 5. The demographic variables of the studied sample

\begin{tabular}{lll}
\hline Characteristics & Description & \\
\cline { 2 - 3 } & Value & Percentage \\
\hline Age & $\mathrm{N}=480$ & $100 \%$ \\
\hline $18 \sim 25$ years old & 63 & $13.13 \%$ \\
\hline $25 \sim 35$ years old & 228 & $47.50 \%$ \\
\hline Over 35 years old & 189 & $39.37 \%$ \\
\hline Education & $\mathrm{N}=480$ & $100 \%$ \\
\hline High-school degree & 80 & $16.67 \%$ \\
\hline Bachelor degree & 331 & $68.96 \%$ \\
\hline Master/Doctor degree & 69 & $14.37 \%$ \\
\hline Average food expenditure per month in a household & $\mathrm{N}=480$ & $100 \%$ \\
\hline $8 \sim 14$ million VND & 105 & $21.88 \%$ \\
\hline $14 \sim 20$ million VND & 192 & $40 \%$ \\
\hline $20 \sim 26$ million VND & 98 & $20.41 \%$ \\
\hline 26 million VND & 85 & $17.71 \%$ \\
\hline
\end{tabular}

Source: Own market survey in HCM market from August $9^{\text {th }}$ to September $26^{\text {th }}, 2015$.

From Table 5, the respondents with ages from 25 to 35 years old took the largest share of the sample at $47.5 \%$, and about $69 \%$ of the sample had achieved a degree from a college or a university. Since JPW is mostly consumed at high-end restaurants, our study concentrated mainly on the respondents who could be potential adopters. Hence, our sample disproportionately captured the middle age group with high education and upper-middle food expenditure per month. 
Table 6. Descriptive statistics of the main variables

\begin{tabular}{|c|c|c|c|}
\hline & \multirow[t]{2}{*}{ Variable } & \multicolumn{2}{|c|}{ Description } \\
\hline & & Value & Percentage \\
\hline$R_{i}$ & Japanese Wagyu beef Preference & \multicolumn{2}{|c|}{ Mean $=2.79 ;$ Std. $=0.87$} \\
\hline \multirow{2}{*}{ Know1 } & 1=Know information 1 & 70 & $14.60 \%$ \\
\hline & $0=$ Don't know information 1 & 410 & $85.40 \%$ \\
\hline \multirow{2}{*}{ Know2 } & 1=Know information 2 & 38 & $7.90 \%$ \\
\hline & $0=$ Don't know information 2 & 442 & $92.10 \%$ \\
\hline \multirow{2}{*}{ Know3 } & 1=Know information 3 & 107 & $22.30 \%$ \\
\hline & 0=Don't know information 3 & 373 & $77.70 \%$ \\
\hline \multirow{2}{*}{ Exper } & 1= Have eaten Japanese Wagyu beef & 92 & $19.20 \%$ \\
\hline & $0=$ Never eaten Japanese Wagyu beef & 338 & $80.80 \%$ \\
\hline
\end{tabular}

Source: Authors' own representation.

The influences of predictors (shown in Table 2) on the consumer preference toward JPW were investigated via the ordered logit model. The criteria of all models are reported in Table 7. Model (1.2) satisfied the assumption of a proportional odds ratio of the ordered logit regression with the p-value at .948. Hence, we based on model (1.2) when discussing the results of hypothesis testing.

Table 7. The summarized results of the ordered logit regression

\begin{tabular}{lll}
\hline Category & $\mathbf{( 1 . 1 )}$ & $\mathbf{( 1 . 2 )}$ \\
\hline Threshold & & \\
\hline Cut point 1 & -6.520 & -6.681 \\
\hline Cut point 2 & -4.137 & -4.254 \\
\hline Cut point 3 & -1.225 & -1.282 \\
\hline Cut point 4 & 2.298 & 2.254 \\
\hline Predictors & & \\
\hline Know1 & $1.130^{* * *}$ & $1.099^{* * *}$ \\
\hline Know2 & .440 & .582 \\
\hline Know3 & -.214 & -.173 \\
\hline Exper & $1.669^{* * *}$ & $1.754^{* * *}$ \\
\hline LuxPrefer & $.577^{* * *}$ & $.683^{* *}$ \\
\hline Price & $-.669^{* * *}$ & $-.586^{* * *}$ \\
\hline Price*Know1 & & .015 \\
\hline Price*Know2 & & .382 \\
\hline Price*Know3 & & $-.536^{* * *}$ \\
\hline LuxPrefer*Know1 & & .263 \\
\hline LuxPrefer*Know2 & & -.735 \\
\hline LuxPrefer*Know3 & & -.334 \\
\hline Age1 & .087 & -.076 \\
\hline Age2 & $.348^{*}$ & $.420^{* *}$ \\
\hline Educ1 & $.465^{* *}$ & $.503^{* *}$ \\
\hline Educ2 & $.590^{*}$ & $.596^{*}$ \\
\hline Expend1 & -.166 & .214 \\
\hline Expend2 & .299 & .231 \\
\hline & & \\
\hline
\end{tabular}


Note. ${ }^{* * *} p<.01 ;{ }^{* *} p<.05 ;{ }^{*} p<0.1$

\begin{tabular}{lll}
\hline Expend3 & -.494 & $-.573^{*}$ \\
\hline Model criteria & & \\
\hline Nagelkerke R $^{2}$ & .407 & .423 \\
\hline -2LL & 952.798 & 940.813 \\
\hline Chi-Square & 225.244 & 237.229 \\
\hline df & 13 & 19 \\
\hline p- value & .006 & .948 \\
\hline
\end{tabular}

Source: Authors' own representation.

Table 8. The standardized logistic coefficients of the model (1.2) applying Menard (2004)

\begin{tabular}{ll}
\hline Predictors & Estimates \\
\hline Know1 & .205 \\
\hline Know2 & .083 \\
\hline Know3 & -.038 \\
\hline Exper & .365 \\
\hline LuxPrefer & .289 \\
\hline Price & -.378 \\
\hline Price*Know1 & .004 \\
\hline Price*Know2 & .070 \\
\hline Price*Know3 & -.165 \\
\hline LuxPrefer*Know1 & .044 \\
\hline LuxPrefer*Know2 & -.091 \\
\hline LuxPrefer*Know3 & -.064 \\
\hline Age1 & -.014 \\
\hline Age2 & .108 \\
\hline Educ1 & .123 \\
\hline Educ2 & .110 \\
\hline Expend1 & -.055 \\
\hline Expend2 & .049 \\
\hline Expend3 & -.115 \\
\hline
\end{tabular}

Note. $R_{0(1.1)}^{2}=0.36 ; R_{0(1.2)}^{2}=0.38$

Source: Authors' own representation.

The results of the model (1.2) indicated the hypotheses of the prior brand knowledge (H1) and the usage experience (H2) were statistically consistent at $p$-value < .01. However, only information 1 made a significant impact on JPW preference $\left(\beta_{3}=1.099\right.$ at $p$-value $\left.<.01\right)$. Moreover, the positive impact of eating experience $\left(\beta_{6}=1.754\right.$ at $p$-value $\left.<.01\right)$ could be seen as an indicator of satisfaction after trying the real product. H3 was supported, as the standardized coefficient of usage experience was larger than the knowledge variables at $p$-value <.01. Furthermore, the AME and APE of usage experience were bigger than those of brand knowledge conditioned on the price at the mean value, as shown in Table 9. Alternatively, one might expect a stronger explanatory ability of usage experience since it generated a larger gap in the probability at high preference levels for JPW than the brand knowledge. 
Table 9. The dominance of usage experience and brand knowledge using AME and APE

\begin{tabular}{lll}
\hline Model 1.2 & AME & APE \\
\hline Know1 & .193 & .125 \\
\hline Know2 & .102 & .077 \\
\hline Know3 & -.030 & -.025 \\
\hline Exper & .309 & .208 \\
\hline
\end{tabular}

Note. APE was calculated at value 1 for each variable

Source: Authors' own representation.

H4 was supported with $\beta_{2}=.683$ at $p$-value $<.01$. Consumers position JPW in the high-grade beef cluster at introduction; alternatively, the image of JPW in consumer perception matched its core value. The insignificant impact of the interaction term between high-grade beef attitude and the prior knowledge indicated external information seemed to be not strong enough to moderate the effect of emerging need for private adoption.

The effect of price in the model (1.2) followed microeconomics theory, as $\beta_{1}=-.586$ at $p$-value <.01. However, H5 was not supported since the interaction term with Know3 was negative at $p$-value $<.01$, and no significant impacts of other information kinds were observed. Consumers with information 3 seemed to be more sensitive to price than ones without this information. This finding highlighted the consideration of advertising claims and various price levels in the introducing strategy for JPW.

The economic value of information could be calculated in relation to price according to the cost-benefit approach. Price as a monetary cost could be compared to the benefit of brand information in decision-making before real purchasing, and the added value of brand information was expressed as $-\frac{\left(\beta_{\text {Know }}+\beta_{\text {Price } * \text { Know Price }}\right)}{\beta_{\text {Price }}}$

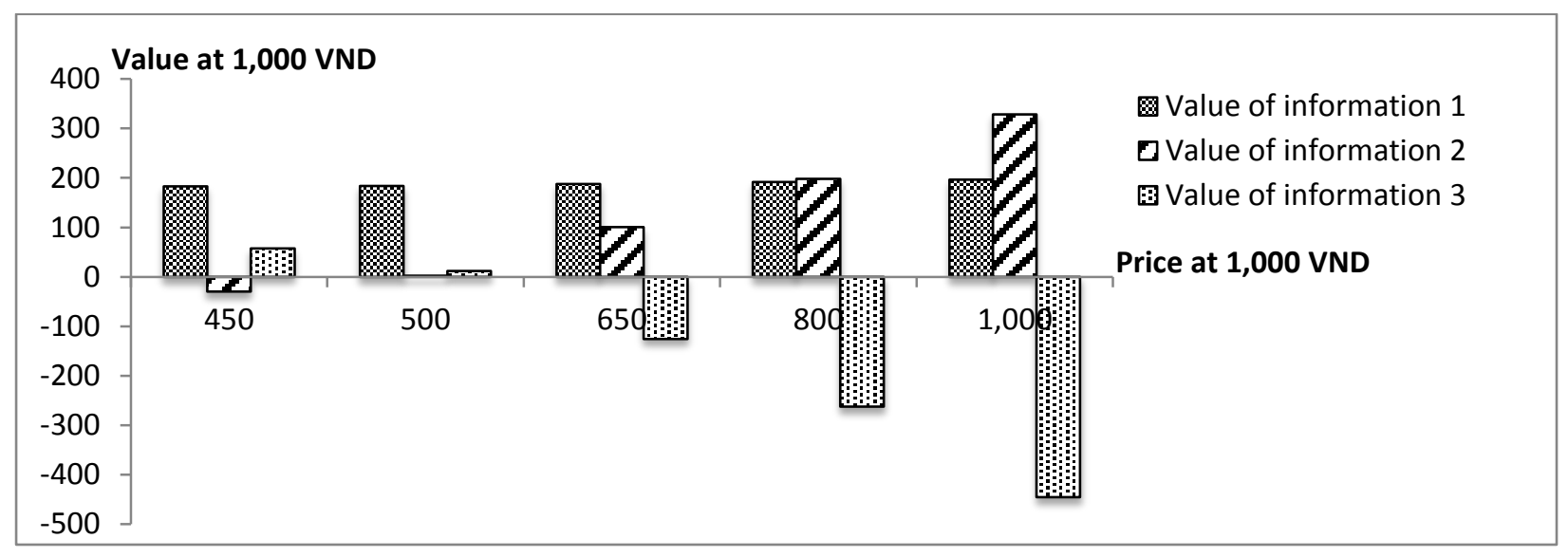

Figure 2. The added value of the information

Source: Authors' own representation.

Based on model (1.2), the consumers with clarified information are willing to pay an additional 190,000 VND on average than those without this information. Figure 2 also showed the high correlation of the value of information 3 with price, while a relatively stable value could be seen for information 1 . 


\section{Discussion}

The empirical results indicated the importance of brand information the introduction stage since consumers with prior brand information tended to have the higher preference for JPW. Furthermore, the impacts of brand information on consumer adoption varied with the advertising contents. Among three alternatives to define JPW in the consumer perception by information in ads, the distinction information (information 1) showed the highest economic added value while the value reduction was seen for the similar information (information 3). Previous studies indicated the positive impacts of prior knowledge on the attitude, purchased intention and purchased behavior. However, the empirical results of three advertising scenarios showed the existence of negative impacts. Some kinds of information could generate the bias in perception and lead to a reduction in the price premium for a new brand/product.

The significant positive impact of information 1 indicated its efficacy in communication during the adoption process. This information differentiates JPW from the current competitors by focusing on two core values, the outstanding pedigree of the beef cattle (Wagyu) and the country-of-origin (made in Japan). It expressed the strength of this combination in positioning and diffusing this beef since kind of food and countryof-origin could be the essential cues in consumer's quality perception of a new beef (Verbeke and Ward, 2006; Alfnes, 2004; Bredahl, 2004; Schnettler et al., 2008).

The negative impact of information 3 indicated consumers, who do not know information 3, tend to evaluate JPW at a higher level of preference. This outcome highlighted the concerns about the impact of information about related brands and the order-of-entry in the consumer cognitive sequence (Kardes and Kalyanaram, 1992; Carpenter and Nakamoto, 1989; 1990; Sujan and Bettman, 1989). Hypothetically, we believed that prior understanding of the similarity between the leading brand (Kobe beef) and JPW would bring higher preference for the late-entrant brand-JPW. However, consumers with information 3 seemed to resist JPW at the early stage. One possibility is the existence of Kobe beef in the Vietnamese market can generate consumers' concerns about uncertainties the following related brand - Japanese Wagyu beef. The behavior of the group with the information 3 could be seen as evidence of a risk-aversion attitude when they can perceive the uncertainties of the new product/brand using retrieval knowledge.

The significantly positive influence of experience indicated consumers' satisfaction after eating. Experience-based knowledge became an indicator of postadopting purchase (Ajzen, 1991; Pieniak et al., 2010; Bredahl, 2004) as well as a positive multiplier in the diffusion process (Rogers, 2003).

\section{Conclusion}

One of the greatest challenges for firms when introducing a new product or brand is how to enhance the market adoption. Previous studies have illustrated the importance of relevant communication with consumers in motivating the desire for satisfaction at the introduction. We argued that providing more brand information could significantly impact the preference for a new brand at the early stage. However, the effects varied by how the new brand/product was defined in the market. The positive outcome was found for being distinct from existing competitors while negative one was for being similar to the leader. Usage experience is the central factor in consumer adoption process since the post-trial satisfaction could be diagnostic for the bias from marketing communication. Hence, the need for consumer education to increase consumer familiarity with new products/brands should be considered. Future research would study on the variety of 
consumer education programs, their impacts on business performance and communicating strategies

Despite intense efforts, our study still retains particular problems in need of future investigation as well as reexamination by other researchers. The first shortcoming of our study comes from the highly restricted requirements of the participants. Three screening questionnaires narrowed the population of the study; hence, the findings should be carefully considered when applying them in other marketing situations. Moreover, due to the specialization of a niche market for a premium beef brand, it seems necessary to be cautious in drawing implications for general marketing practices. Another limitation comes from the methodology to evaluate the prior brand knowledge of respondents. Even though this study tried to diversify the content of brand advertising, the prior knowledge was measured by a dichotomous variable. Hence, a demand exists for precise measurement in future studies instead of Yes/No questions as in this study.

\section{References}

Abernethy, A.M and Franke, G.R. (1996), "The Information Content of Advertising: A Meta-Analysis", Journal of Advertising, Vol. 25 No. 2, pp. 1-17.

Ackerberg, D.A. (2003), "Advertising, Learning and Consumer Choice in Experience Good Markets: A Structural Empirical Examination", International Economic Review, Vol. 44 No. 3, pp. 1007-1040.

Ackerberg, D. A. (2001), "Empirically Distinguishing Informative and Prestige Effects of Advertising", The RAND Journal of Economics, Vol. 32 No. 2, pp. 316-333.

Aertsens, J., Verbeke, W., Mondelaers, K., and Huylenbroeck, G. Van. (2009), "Personal determinants of organic food consumption: a review", British Food Journal, Vol. 111 No. 10, pp. 1140-1167.

Ajzen, I. (1991), "The theory of planned behavior". Orgnizational Behavior and Human Decision Processes, Vol. 50 No. 2, pp. 179-211.

Alba, J. and Hutchinson J.W. (2000), "Knowledge Calibration: What Consumers Know and What They Think They Know," Journal of Consumer Research, Vol. 27 (September), pp. 123-156.

Alfnes, F. (2004), "Stated preferences for imported and hormone-treated beef: application of a mixed logit model", European Review of Agriculture Economics, Vol. 31 No. 1, pp. 19-37.

Angulo, A.M. and Gil, J.M. (2007), "Risk perception and consumer willingness to pay for certified beef in Spain", Food Quality and Preference, Vol. 18 No. 8, pp. 1106-1117.

Baltas, G. and Doyle, P. (2001), "Random utility models in marketing research: A survey", Journal of Business Research, Vol. 51 No. 2, pp. 115-125.

Banović, M., Fontes, M. A., Barreira, M. M., and Grunert, K. G. (2012), "Impact of Product Familiarity on Beef Quality Perception", Agribusiness, Vol. 28 No. 2, pp. 157-172.

Banović, M., Grunert, K. G., Barreira, M. M., and Fontes, M. A. (2009), "Beef quality perception at the point of purchase: A study from Portugal", Food Quality and Preference, Vol. 20, No. 4, pp. 335-342.

Bauer, H.H., and Barnes, S.J. (2005), "Driving Consumer Acceptance of Mobile Marketing: a Theoretical Framework and Empirical Study", Journal of Electronic Commerce Research, Vol. 6, No. 3, pp. 181-192.

Becker, G.S. and Murphy, K.M. (1993), "A Simple Theory of Advertising as a Good or Bad", Quarterly Journal of Economics, Vol. 108, No. 4, pp. 941-964.

Bian, X., and Moutinho, L. (2011), "The role of brand imagine, product involvement, and 
knowledge in explaning consumer purchase behaviour of counterfeits: Direct and indirect effects", European Journal of Marketing, Vol. 45, No. 1, pp. 191-216.

Brakus, J.J., Schmitt, B. H., Zarantonello, L., Calkins, R. D., and Zarantonello I. L. (2009), "Brand Experience: What Is It? How Is It Measured? Does It Affect Loyalty? ", Journal of Marketing, Vol. 73, No.3, pp. 52-68.

Bredahl, L. (2004), "Cue utilisation and quality perception with regard to branded beef", Food Quality and Preference, Vol. 15, No. 1, pp. 65-75.

Brester, G.W. and Schroeder, T.C. (1995), "The Impacts of Brand and Generic Advertising on Meat Demand", American Journal of Agricultural Economics, Vol. 77, No. 4, pp. 969-979.

Brown, S.L. and Eisenhardt, K.M. (1995), "Product Development: Past Research, Present Findings, and Future Directions", Academy of Management Review, Vol. 20, No. 2, pp. 343-378.

Carpenter, G. S., and Nakamoto, K. (1989), "Consumer Preference Formation and Pioneering Advantage", Journal of Marketing Research, Vol. 26, No. 3, pp. 285-298.

Carpenter, S.G., and Nakamoto, K. (1990), "Competitive Strategies for Late Entry in a market with a Dominant Brand", Management Science, Vol. 36 No. 10, pp. 12681287.

Cooper, R.G. (1979), "The Dimensions of Industrial New Product Success and Failure", Journal of Marketing, Vol. 43, No. 3, pp.93-103.

Cooper, R.G. and Kleinschmidt, E.J. (1987), "New products: What separates winners from losers?", The Journal of Product Innovation Management, Vol. 4, No. 3, pp. 169184.

Erdem, T., Keane, M.P. and Sun, B. (2008), "The impact of advertising on consumer price sensitivity in experience goods markets", Quantitative Marketing and Economics, Vol. 6, No. 2, pp. 139-176.

Erevelles, S., Roy, A. and Yip, L.S.C. (2001), "The universality of the signal theory for products and services", Journal of Business Research, Vol. 52, No. 2, pp. 175-187.

Ford, J.K., MacCallum, R.C. and Tait, M. (1986), "The Application of Exploratory Factor Analysis in Applied Psychology: A Critical Review and Analysis", Personnel Psychology, Vol. 39, No. 2, pp. 291-314.

Frambach, R.T., Prabhu, J. and Verhallen, T.M.M. (2003), "The influence of business strategy on new product activity: The role of market orientation", International Journal of Research in Marketing, Vol. 20, No. 4, pp. 377-397.

Froehlich, E.J., Carlberg, J.G. and Ward, C.E. (2009), "Willingness-to-pay for fresh brand name beef", Canadian Journal of Agricultural Economics, Vol. 57, No. 1, pp. 119137.

Gale, F. \& Huang, K. (2007), "Demand for Food Quantity and Quality in China", Quality, Vol. 32, pp. 69-115.

Gandhi, V.P. \& Zhou, Z. (2014), "Food demand and the food security challenge with rapid economic growth in the emerging economies of India and China", Food Research International, Vol. 63, pp. 108-124.

Grunert, K.G., Bredahl, L. and Brunsø, K. (2004), "Consumer perception of meat quality and implications for product development in the meat sector - A review", Meat Science, Vol. 66, No. 2, pp. 259-272.

Ha, H.-Y. and Perks, H. (2005), "Effects of consumer perceptions of brand experience on the web: Brand familiarity, satisfaction and brand trust", Journal of Consumer Behaviour, Vol. 4, No. 6, pp. 438-452.

Ha, J. and Jang, S. (2010). "Perceived values, satisfaction, and behavioral intentions: The 
role of familiarity in Korean restaurants", International Journal of Hospitality Management, Vol. 29, No. 1, pp. 2-13

Hubacek, K., Guan, D. and Barua, A. (2007), "Changing lifestyles and consumption patterns in developing countries: A scenario analysis for China and India", Futures, Vol. 39, No. 9, pp. 1084-1096.

Hughner, R. S., McDonagh, P., Prothero, A., Shultz, C. J., and Stanton, J. (2007), "Who are organic food consumers? A compilation and review of why people purchase organic food", Journal of Consumer Behaviour, Vol. 6, No. 3, pp. 1-17.

Johnson, E.J. and Russo, J.E. (1984), "Product Familiarity and Learning New Information", Journal of Consumer Research, Vol. 11, No.1, pp. 542-550.

Kardes, F.R. and Kalyanaram, G. (1992), "Order-of-entry effects on consumer memory and judgment: An information integration perspective", Journal of Marketing Research, Vol. 29, No. 3, pp. 343-357.

Keller, K.L. (2009), "Building strong brands in a modern marketing communications environment", Journal of Marketing Communications, Vol. 13, No. 2-3, pp. 139155.

Lange, C., Issanchou, S. and Combris, P. (2000), "Expected versus experienced quality: trade-off with price", Food Quality and Preference, Vol. 11, No. 4, pp. 289-297.

Lange, C., Rousseau, F. and Issanchou, S. (1998), "Expectation, liking and purchase behaviour under economical constraint", Food Quality and Preference, Vol. 10, No. 1, pp. 31-39.

Lin, L.Y., and Chen, S.C. (2006), "The influence of the country-of-origin image, product knowledge, and product involvement on consumer purchase decisions: an empirical study of insurane and catering service in Taiwan", Journal of Consumer Marketing, Vol. 23, No. 5, pp. 248-265.

Lobb, A.E., Mazzocchi, M. and Traill, W.B. (2007), "Modelling risk perception and trust in food safety information within the theory of planned behaviour", Food Quality and Preference, Vol. 18, No. 2, pp. 384-395.

Maclnnis, D.J. and Jaworski, B.J., (1989), "Information Processing from Advertisements: Toward an Integrative Framework", Journal of Marketing, Vol. 53, No. 4, pp. 1-23.

Maenpaa, K., Kale, S.H., Kuusela, H. and Mesiranta, N. (2008), "Consumer perceptions of Internet banking in Finland: The moderating role of familiarity", Journal of Retailing and Consumer Services, Vol. 15, No. 4, pp. 266-276.

Maheswaran, D. and Sternthal, B. (1990), "The Effects of Knowledge, Motivation, and Type of Message on Ad Processing and Product Judgments", Journal of Consumer Research, Vol. 17, pp. 66-73.

Manski, C.F. (1977), "The structure of random utility models", Theory and Decision, Vol. 8, No. 3, pp. 229-254.

Menard, S. (2004), "Six approaches to calculating standardized logistic regression coefficients", American Statistician, Vol. 58, No. 3, pp. 218-223.

Menictas, C., Wang, P.Z. and Louviere, J.J. (2012), "Assessing the validity of brand equity constructs", Australasian Marketing Journal, Vol. 20 No. 1, pp. 3-8.

Mood, C. (2010), "Logistic regression: Why we cannot do what We think we can do, and what we can do about it", European Sociological Review, Vol. 26 No. 1, pp. 67-82.

Moreau, C.P, Lehmann, D.R, and Markman, A.B. (2001), "Entrenched Knowledge Structures and Consumer Response to New Products", Journal of Marketing Research, Vol. 38 No. 19, pp. 14-29

Mothersbaugh, D. L., Feick, L., Park, C. W., Mothersbaugh, D. L., and Feick, L. (1994), "Consumer Knowledge Assessment", Journal of Consumer Research, Vol. 21, No. 1, 
pp. 71-82.

Myers, S. and Marquis, D. (1969), "Successful industrial innovation: a study of factors underlying innovation in selected firms", National Science Foundation, pp. 69-71.

Nelson, P. (1970), "Information and Consumer Behavior", Journal of Political Economy, Vol. 78, No. 2, pp. 311-329.

Nelson, P. (1974), "Advertising as Information", Journal of Political Economy, Vol. 82, No. 4, pp. 729-754.

Nicosia, Franceso M. (1966), Consumer Decision Process, Prentice Hall: Engelwood Cliffs, N.J.

Pieniak, Z., Aertsens, J. and Verbeke, W. (2010), "Subjective and objective knowledge as determinants of organic vegetables consumption", Food Quality and Preference, Vol. 21, No. 6, pp. 581-588.

Pingali, P. (2007), "Westernization of Asian diets and the transformation of food systems: Implications for research and policy", Food Policy, Vol. 32, No. 3, pp. 281-298.

Radecki, M. Carem, and Jaccard, J. (1995), "Perception of knowledge, actual knowledge, and information search behaviour", Journal of Experimental Social Psychology, Vol. 31, No. 2, pp. 107-138.

Raju, P.S., Lonial, S.C. and Glynn Mangold, W. (1995), "Differential Effects of Subjective Knowledge, Objective Knowledge, and Usage Experience on Decision Making: An Exploratory Investigation", Journal of Consumer Psychology, Vol. 4 No. 2, pp. 153180.

Rogers, E. (1983), Diffussion of Innovations, The Free Press: New York.

Rogers, E.M. (2003), Diffusion of innovations, The Free Press: New York.

Saaksjarvi, M. (2003), "Consumer adoption of technological innovations", European Journal of Innovation Management, Vol. 6, No. 2, pp. 90-100.

Schiffman, L.G. and Kanuk, L.L. (2007), "Consumer behavior", Pearson Prentice Hall: Upper Saddle River, N.J.

Schmidt, J.B. and Spreng, R.A. (1996), "A proposed model of external consumer information search", Journal of the Academy of Marketing Science, Vol. 24, No. 3, pp. 246-256.

Schnettler, B., Ruiz, D., Sepúlveda, O., and Sepúlveda, N. (2008), "Importance of the country of origin in food consumption in a developing country", Food Quality and Preference, Vol. 19, No. 4, pp. 372-382.

Smith, R.E., and Swinyard, W.R. (1983), "Attitude-Behavior Consistency: The Impact of Product Trial versus Advertising", Journal of Marketing Research, Vol. 20, No. 3, pp. 257-267.

Stigler, G.J. (1961), "The Economics of Information", The Journal of Political Economy, Vol. 69, No. 3, pp. 213-225.

Sujan, M., and Bettman, R.J. (1989), "The effects of brand positioning strategies on consumer's brands and category perception: Some insights from shcma research", Journal of Marketing Research, Vol. 26, No. 11, pp. 454-467.

Tepper, B.J., Choia, Y. and Nayga, R.M.J. (1997), "Understanding Food Choice in Adult Men: Influence of Nutrition Knowledge, Food Beliefs, and Dietary Restraint", Food Quality and Preference, Vol. 8, No. 4, pp. 307-317.

Thøgersen, J. (2002), "Direct Experience and the Strength of the Personal Norm Behavior Relationship", Psychology \& Marketing, Vol. 19 No. 10, pp. 881-893.

Thøgersen, J., Haugaard, P., and Olesen, A. (2010), "Consumer responses to ecolabels", European Journal of Marketing, Vol. 44 No. 11, pp. 1787-1810. 
Tonidandel, S. and LeBreton, J.M. (2010), "Determining the Relative Importance of Predictors in Logistic Regression: An Extension of Relative Weights Analysis", Organizational Research Methods, Vol. 13 No. 4, pp. 767-781.

Tran, T.T, Moritaka, M., and Fukuda, S. (2017), "Country of Origin, Price Consciousness, and Consumer Innovativeness at Food Service Outlets in Developing Markets: Empirical Evidence from Brands of Imported Beef in Vietnam", International Journal of Marketing Studies, Vol. 9, No. 3, pp. 50-63.

Tseng, F.M. and Hu, Y.C. (2009), "Quadratic-interval Bass model for new product sales diffusion", Expert Systems with Applications, Vol. 36, No. 4, pp. 8496-8502.

Van Kleef, E., Van Trijp, H.C.M, and Luning, P. (2005). "Consumer research in the early stages of new product development: a critical review of methods and techniques", Food Quality and Preference, Vol. 16, No. 3, pp. 181-201.

Verbeke, W. and Ward, R.W. (2006), "Consumer interest in information cues denoting quality, traceability and origin: An application of ordered probit models to beef labels", Food Quality and Preference, Vol. $17 \mathrm{~m}$ No. 6, pp. 453-467.

Voon, J. P., Sing, K., Agrawal, A., Voona, J., Nguib, K., and Agrawalc, A. (2011), "Determinants of willingness to purchase organic food: An exploratory study using structural equation modelling", International Food and Agribusiness Management Review, No. 14, Vol. 2, pp. 103-120.

Wood, S. L., and Lynch, J. G. Jr. (2002), "Prior knowledge and complacency in new product learning", Journal of Consumer Research, Vol. 29, No. 3, pp. 416-426.

Xie, Y. and Manski, C.F. (1989), "The logit Model and Response-Based Samples", Sociological Methods \& Research, Vol. 17, No 3, pp. 238-302.

Zhou, K.Z. and Nakamoto, K. J. (2007), "How do enhanced and unique features affect new product preference? The moderating role of product familiarity", Journal of the Academy of Marketing Science, Vol. 35, No. 1, pp. 53-62.

Zhu, D.H., and Chang, Y.P. (2015), "Effects of Interactions and Product Information on Initial Purchase Intention in Product Placement in Social Games: The Moderating Role of Product Familiarity", Journal of Electronic Commerce Research, Vol. 16, No. 1, pp. 22-33. 